\title{
Research on English Majors' Business English Writing based on the Theory of Lexical Chunks
}

\author{
Liaoliao ZHANG \\ Wuhan Huaxia University of Technology, Wuhan, 430223, China \\ email: 164073893@qq.com
}

Key words: English majors; BE writing; lexical chunk; English teaching

\begin{abstract}
As to Business English writing (BE writing), one of the most key courses for business English majors, it is one of the essential skills in the involvement of international business activities. The research is to apply the theory of lexical chunks to Business English Writing. This research is a trial to find out the lexical phrases used in BE writing and the students' writing proficiency which also exists inadequate proof in analysis and certification that are needed to be improved in the future studies. The conclusion is that Students from the experiment class adopt the lexical chunk approach, use larger vocabulary and more complicated grammar structures in their Business English Writing with fewer mistakes. Lexical chunks can promote students' vocabulary and grammar.
\end{abstract}

\section{Introduction}

With the development of economic globalization, and China's entry to WTO, trade between China and the world has increased rapidly, with more and more frequent business contact and communication among different countries and regions. [1] As a result, those who are working in business world, particularly concerning import and export, utilize various ways to build and keep good relationship with each other. In such a case, communication in written English is becoming an essential tool between Chinese and people from all over the world. In other words, business English writing is becoming increasingly important in today's business world. In recent years, an increasing number of linguists have done much research on the theory of lexical chunks and made a lot of achievements. [2] In teaching practice, the author has witnessed students' difficulties and problems in BE writing. [3] It is common to see many spelling mistakes, grammatical mistakes, wrong sentence structures, and incorrect punctuation in BE writing. [4] [5] In general speaking, although students try their best to complete BE writing, their BE writing proficiency is far from satisfaction. Being poor in organizing the structure of the whole writing is a serious problem because there are not sufficient transitional expressions or linking devices used to indicate it in BE writing.

\section{Methodology}

\section{A. Participants}

The subjects surveyed are from the 80 juniors majoring in English in Wuhan Huaxia University of Technology in Hubei Province. They are divided into two classes randomly, each class with 40 students. Class A adopts the traditional approach, which focuses on grammar and vocabulary. Class $\mathrm{B}$ is the experimental class with the applying the theory of lexical chunks in to Business English Writing.

\section{B. Research Instrument}

In this study, questionnaires are adopted. By referring to many papers and books about BE writing, the author found that business lexical chunks makes great influence in BE writing. Students 
from the two classes share the same teaching schedule and the same text book. At the beginning, the Pre-questionnaire is designed to research on students' attitude toward Business English Writing, students' understanding of Business English Writing and lexical chunks; students' problem-solving approach. The questionnaire has 10 multiple-choice questions. The Post-Questionnaire will be held at the end of the course. It consists of 10 multiple-choice questions, which purpose is to see whether the application of the theory of lexical chunks into Business English Writing is effective or not.

\section{Data Collection}

All 80 students hand in their compositions and questionnaire papers. The pre-test and post-test are all formal examinations. The data of pre-test, post-test, questionnaires will be analyzed by Microsoft Excel and SPSS 19.0.

\section{Results and Discussion}

The author tries to integrate the BE writing course with cultivating -----to find applicable teaching methods as well as to provide some suggestions to the teaching of business English and BE writing.

\section{A. The Results of the Pre-test}

Table 1 The comparison of Score of composition A in Pre-test

\begin{tabular}{|l|l|l|l|l|}
\hline \multirow{2}{*}{ Group score } & \multicolumn{2}{|l|}{ Class A } & \multicolumn{2}{l|}{ Class B } \\
\cline { 2 - 5 } & $\begin{array}{l}\text { The number of } \\
\text { people }\end{array}$ & percentage & $\begin{array}{l}\text { The number of } \\
\text { people }\end{array}$ & percentage \\
\hline $13-15$ & 4 & $10 \%$ & 4 & $10 \%$ \\
\hline $10-12$ & 11 & $27.5 \%$ & 11 & $27.5 \%$ \\
\hline $7-9$ & 14 & $35 \%$ & 13 & $32.5 \%$ \\
\hline $4-6$ & 10 & $25 \%$ & 11 & $27.5 \%$ \\
\hline $1-3$ & 1 & $2.5 \%$ & 1 & $2.5 \%$ \\
\hline 0 & 0 & $0 \%$ & 0 & $0 \%$ \\
\hline Total & 40 & $100 \%$ & 40 & $100 \%$ \\
\hline Average & 8.45 & & 8.4 & \\
\hline Standard Deviation & 2.578 & & 2.51 & \\
\hline
\end{tabular}

Table 2 The comparison of Score of composition B in Pre-test

\begin{tabular}{|l|l|l|l|l|}
\hline \multirow{2}{*}{ Group score } & \multicolumn{2}{|l|}{ Class A } & \multicolumn{2}{l|}{ Class B } \\
\cline { 2 - 5 } & $\begin{array}{l}\text { The number of } \\
\text { people }\end{array}$ & percentage & $\begin{array}{l}\text { The number of } \\
\text { people }\end{array}$ & percentage \\
\hline $17-20$ & 2 & $5 \%$ & 3 & $7.5 \%$ \\
\hline $13-16$ & 9 & $22.5 \%$ & 7 & $17.5 \%$ \\
\hline $9-12$ & 15 & $37.5 \%$ & 16 & $40 \%$ \\
\hline $5-8$ & 11 & $27.5 \%$ & 10 & $25 \%$ \\
\hline $1-4$ & 3 & $7.5 \%$ & 4 & $10 \%$ \\
\hline 0 & 0 & $0 \%$ & 0 & $0 \%$ \\
\hline Total & 40 & $100 \%$ & 40 & $100 \%$ \\
\hline Mean & 10.475 & & 10.025 & \\
\hline Standard Deviation & 3.64 & 3.76 & \\
\hline
\end{tabular}


Seen from the table 1 and table 2, the average grades of the composition A are 8.45 and 8.4, while the average grades of composition B are 10.475 and 10.025 . The standard deviations of composition A are 2.578 and 2.51, while the standard deviations of composition B are 3.64 and 3.76. The figures of the two classes are similar to each other, which reflect that the English levels of the students in two classes are similar at the beginning of the experiment. Actually, the students from the whole university randomly select the course. Although there are slight differences in the distribution of their scores, the averages and standard deviations, no significant differences exist between the two classes. We can conclude that the experiment will be valid and convincing.

Table 3 the lexical chunks of the two compositions in Pre-test

\begin{tabular}{|l|l|l|l|l|}
\hline \multirow{2}{*}{} & \multicolumn{2}{|l|}{ Class A } & \multicolumn{2}{l|}{ Class B } \\
\cline { 2 - 5 } & number & percentage & number & percentage \\
\hline Number & 40 & & 40 & \\
\hline Total words & 6645 & & 6672 & \\
\hline Average words & 166.125 & & 164.3 & $1.8 \%$ \\
\hline Polwwords & 121 & $0.24 \%$ & 15 & $0.23 \%$ \\
\hline Institutionalized expressions & 16 & $3.07 \%$ & 204 & $3.1 \%$ \\
\hline Phrasal constraint & 204 & $3.25 \%$ & 218 & $3.32 \%$ \\
\hline Sentence builder & 216 & $8.38 \%$ & 555 & $8.44 \%$ \\
\hline Total & 557 & & & \\
\hline
\end{tabular}

Table 3 offers us the details of writing performances of the two classes in the Pre-test. There are 557 lexical chunks used in their compositions.

\section{B. The Results of the Post-test}

Table 4 The comparison of writing scores of composition A in Post-test

\begin{tabular}{|l|l|l|l|l|}
\hline \multirow{2}{*}{ Group score } & \multicolumn{2}{|l|}{ Class A } & \multicolumn{2}{l|}{ Class B } \\
\cline { 2 - 5 } & $\begin{array}{l}\text { The number of } \\
\text { people }\end{array}$ & percentage & $\begin{array}{l}\text { The number of } \\
\text { people }\end{array}$ & percentage \\
\hline $13-15$ & 8 & & 11 & \\
\hline $10-12$ & 12 & & 15 & \\
\hline $7-9$ & 12 & & 10 & \\
\hline $4-6$ & 7 & & 3 & \\
\hline $1-3$ & 1 & & 1 & \\
\hline 0 & 0 & & 0 & $100 \%$ \\
\hline Total & 40 & $100 \%$ & 40 & \\
\hline Average & 9.475 & & 10.65 & \\
\hline Standard Deviation & 2.94 & & 2.66 & \\
\hline
\end{tabular}


Table 5 The comparison of writing scores of composition B in Post-test

\begin{tabular}{|c|c|c|c|c|}
\hline \multirow[t]{2}{*}{ Group score } & \multicolumn{2}{|l|}{ Class A } & \multicolumn{2}{|l|}{ Class B } \\
\hline & $\begin{array}{l}\text { The number of } \\
\text { people }\end{array}$ & percentage & $\begin{array}{l}\text { The number of } \\
\text { people }\end{array}$ & percentage \\
\hline $17-20$ & 5 & 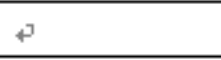 & 8 & 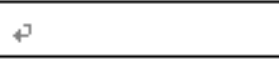 \\
\hline $13-16$ & 13 & 8 & 16 & 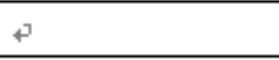 \\
\hline $9-12$ & 13 & 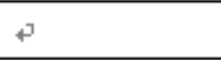 & 13 & 8 \\
\hline $5-8$ & 6 & 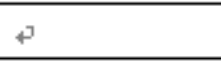 & 2 & 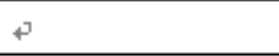 \\
\hline $1-4$ & 3 & 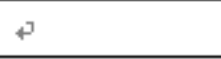 & 1 & 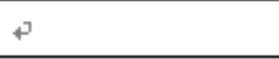 \\
\hline 0 & 0 & 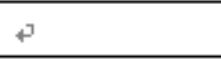 & 0 & 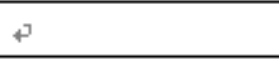 \\
\hline Total & 40 & 3 & 40 & 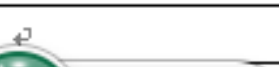 \\
\hline Mean & \multicolumn{2}{|l|}{11.25} & 13.3 & $0 \mathrm{~K} / \mathrm{s}+\mathrm{P}$ \\
\hline Standard Deviation & \multicolumn{2}{|l|}{3.54} & 3.38 & 1 \\
\hline
\end{tabular}

Seen from the table 4 and table 5, the average grades of the composition A are 9.475 of Class A and 10.65 of Class B, while the average grades of composition B are 11.25 of Class A and 13.3 of Class B. The standard deviations of composition A are 2.94 of Class A and 2.66 of Class B, while the standard deviations of composition B are 3.54 of Class A and 3.38 of Class B. From the date above, it is clear that Class B makes greater progress than Class A after 11 weeks study. Class B achieves higher grades by using more lexical chunks in their compositions.

Table 6 The lexical chunks of the two compositions in Post-test

\begin{tabular}{|c|c|c|c|c|}
\hline \multirow[t]{2}{*}{ 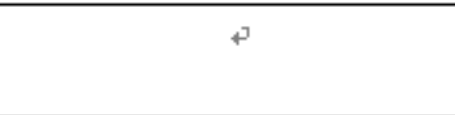 } & \multicolumn{2}{|l|}{ Class A } & \multicolumn{2}{|l|}{ Class B } \\
\hline & number & percentage & number & percentage \\
\hline Number & 40 & (n- & 40 & $p^{\prime}$ \\
\hline Total words & 6623 & (3) & 7115 & (n) \\
\hline Average words & 165.6 & (3) & 177.8 & (n) \\
\hline Polvwords & 139 & $2.1 \%$ & 197 & $2.77 \%$ \\
\hline Institutionalized expressions & 93 & $1.4 \%$ & 113 & $1.59 \%$ \\
\hline Phrasal constraint & 192 & $2.9 \%$ & 258 & $3.63 \%$ \\
\hline Sentence builder & 201 & $3.04 \%$ & 225 & $3.16 \%$ \\
\hline Total & 625 & $9.43 \%$ & 793 & $11.15 \%$ \\
\hline
\end{tabular}

It can be seen from Table 6 that, in all their compositions, Class A uses 625 lexical chunks, making up 9.45\% of whole compositions while Class B uses 793 lexical chunks, making up 11.15\% of whole compositions. More sentence builders and phrasal constraints are used by the students of Class B than the students of Class A. this contributes a lot to the higher scores of Class B. Students in Class B usually employ some complex and various types of lexical chunks in their writings, rather than repeating the similar ones again and again.

From the above six tables, It is clearly that after 11 weeks study, Class B improves much higher that Class A. Clear differences exist in the post-test results. It is apparent that after the English learning, both classes improve quite a lot. However, clearly students of Class B employ more lexical chunks and more various expressions than those of Class A. The lexical chunks in their 
compositions are also more complex and frequent. This proves that the lexical chunk approach has transparent positive effect on Business English Writing.

\section{Conclusion}

Lexical chunk approach can save a lot of time and energy which could be spent to focus on the content as well as grammar and structure. It is clear that using lexical chunks will speed up the Business English Writing. As a result, the lexical chunks used in Business English Writing are very explicit, formal and professional. [6] The experiment proves that lexical chunk approach can help students to improve their Business English Writing performance. It can improve students, English competence and proficiency. Compared with the traditional approach, it is a very effective way that teachers should adopt in their teaching of Business English Writing. Teachers are supposed to introduce the lexical chunk theory to students and emphasize its importance at the beginning. Further, the author suggested that universities increase courses relating to lexical chunk approach to the curriculum, and offer such courses to both business-oriented majors. Besides, there are also other factors affecting students' performance in Business English Writing. Further researches should take these factors into consideration.

\section{References}

[1] Glenn S.Levine. Global Simulation: A Student - Centered, Task - Based Format for Intermediate Foreign Language Courses[J]. Foreign Language Annals . 2008 (1)

[2] Wray, A. (2002). Formulaic Language and the Lexicon. Cambridge: Cambridge University Press.

[3] Harmer, J. (2001). The Practice of English Language Teaching. Beijing: Foreign Language Teaching and Research Press.

[4] Becker, J. (1975). The Phrasal Lexicon. Cambridge: Bolt, Beranek and Newman.

[5] Bailey,K.M.Working for Weshbeck:A Review of the Washback Concept in Language Testing. Language Testing . 1996

[6] Lewis, M. (2000). Teaching collocations. Hove; Language Teaching Publications. 